\title{
Turistlerin Terör Riski Algısı ve Riskle Başa Çıkma Davranışları*
}

Tourists' Perception of Terrorism Risk and Risk Handling Behavior

\author{
Burçin KIRLAR CAN**, Işıl ÖZGEN*** \\ ** (Sorumlu Yazar), Dr., Pamukkale Üniversitesi, Turizm Fakültesi, Turizm İşletmeciliği Bölümü, Kınıklı Kampüsü, 20160, Pamukkale, Denizli. \\ E-posta: burcink@pau.edu.tr \\ ORCID: 0000-0003-0819-3014 \\ *** Doç. Dr., Dokuz Eylül Üniversitesi, İşletme Fakültesi, Turizm Işletmeciliği Bölümü, Kaynaklar Yerleşkesi, 35390, Buca, İzmir. \\ E-posta: isil.goksu@deu.edu.tr \\ ORCID: 0000-0003-4142-1138
}

MAKALE BILGILERI

Makale işlem bilgileri:

Gönderilme tarihi: 29 Eylül 2019

Düzeltme: 13 Aralık 2019

Düzeltme: 16 Ocak 2020

Kabul: 20 Ocak 2020

Anahtar sözcükler: Terör, Risk algısı, Riskle başa çıkma, Turist davranışı.

\section{ARTICLE INFO}

Article history:

Submitted: 29 September 2019

Resubmitted: 13 December 2019

Resubmitted: 16 January 2020

Accepted: 20 January 2020

Key words: Terrorism, Risk perception, Risk handling, Tourist behavior.

\begin{abstract}
$\ddot{O Z Z}$
Bireylerin güvenliğini tehdit eden terör saldırıları, politik, ekonomik, psikolojik ve sosyolojik açıdan olumsuz sonuçlar doğurmaktadır. Turistler, teröre yönelik risk algıları doğrultusunda riskten kaçınma veya risklere rağmen seyahat etme eğilimi gösterebilmektedir. Çalışmanın amacı, turistlerin teröre yönelik risk algılarını tespit ederek riskle başa çıkma davranışlarını ortaya koymaktır. Çalışmada nitel araştırma yöntemi benimsenmiş; veriler, derinlemesine görüşme ve senaryo teknikleri aracılığıyla toplanmıştır. Araştırmanın içeriğini, derinliğini ve niteliğini zenginleştirmek ve farklı bakış açılarını ortaya koymak için maksimum çeşitlilik örneklemesi kullanılmıştır. Elde edilen veriler niteliksel içerik analizi ile çözümlenmiştir. Bulgular, kuramsal çerçeve doğrultusunda katılımcıların ifadeleriyle birlikte yorumlanmıştır.
\end{abstract}

\section{GíRiş}

Uluslararası turizm hareketliliği, turistlerin alg1ladığı tüm risklere rağmen yıllar içinde istikrarlı bir seyir izlemiştir. Terör, yıllar içinde turistlerin algıladığı risklerin başında gelmiş ve seyahat kararı üzerinde önemli rol oynamış (Reisinger ve Mavondo 2005); buna rağmen insanları seyahat etme arzusunu deneyimlemekten alıkoyamamış-

\footnotetext{
* Bu çalışma, Dokuz Eylül Üniversitesi Sosyal Bilimler Enstitüsü Turizm İşletmeciliği Dalında, Doç. Dr. Işıl Özgen danışmanlığında yazılan, "Turistlerin Terör Riski ile Başa Çıkma Davranışları ve Seyahat Uyarılarına Bakış Açıları" başlıklı doktora tezinden üretilmiştir.
}

tır (Larsen vd. 2011). Bu çalışma, turistlerin terör riski karşısında verdiği kararlara ve bu kararlarda etkili olan bilişsel süreçlere odaklanmış ve "risk toplumu", "beklenti" ve "bilgi entegrasyonu" gibi kuramların varsayımları doğrultusunda temellendirilmiştir.

Çalışma, (a) terörün risk algısı bağlamında turizm üzerindeki etkilerini sosyal ve psikolojik açıdan irdeleyerek farklı bir perspektiften bakması ve alanyazındaki boşluğu doldurması, (b) turistlerin riskler karşısındaki davranışlarını irdelemesi ve bu davranışların ardında yatan bilişsel süreçleri ortaya koyarak alanyazına ve 
kurama katkıda bulunması bakımından önem taşımaktadır. Çalışma, risk algısı ve seyahat uyarılarının neden olduğu krizlerde olumsuz imajın önlenmesi ve iletişim yönetimi açısından yol haritası sunmaktadır.

\section{KAVRAMSAL VE KURAMSAL ÇERÇEVE}

Türkiye, özellikle 2015-2017 yılları arasında sıklıkla risklerle anılmış ve bu risklere bağlı seyahat uyarılarına maruz kalmıştır. Türkiye'nin en fazla uyarıya maruz kaldığı risklerin başında da terör gelmiştir (Kırlar-Can 2018). Terörün yarattığ1 etkinin süresi, yaşanan olayların özelliklerine göre değişkenlik gösterse de etkinin büyüklüğü ekonomik, sosyolojik ve psikolojik bakımdan oldukça şiddetli olabilmektedir (Rittichainuwat ve Chakraborty 2009). Turistlerin riskli algiladığ 1 destinasyonlara seyahat etmek istemediği, teröre yönelik risk algısı arttıkça seyahat kararından vazgeçme, seyahati erteleme veya destinasyonu değiştirme gibi davranışlar sergilediği bilinmektedir (Sharpley vd. 1996; Sönmez ve Graefe 1998a; Reisinger ve Mavondo 2005). Buna rağmen her yerin risk taşıdı ̆̆ı günümüzde (Beck 2006) riskten kaçınan turistler olduğu gibi risk almaya eğilimli ve riskli destinasyonlara seyahat eden turistler de bulunmaktadır.

Turistlerin risk ve belirsizlik altında verdikleri kararları açıklamak için kullanılan kuramlardan biri "Beklenti Kuramı"dır (Prospect Theory). Riskli kararların bağlam içinde değerlendirilmesi gerektiğini savunan kuram, bireylerin riskler karşısında hep aynı davranışları sergilemediğini ve özellikle kazançlardan çok kayıplar olduğunda daha fazla risk alabildiğini ileri sürmektedir (Kahneman ve Tversky 1979). Turistlerin de deneyim veya haz gibi kendilerine fayda sağladıkları durumlarda risklere daha fazla tahammül edebildiği düşünülmektedir (Piekarz vd. 2015). Ancak fiziksel ve finansal kayıpları daha fazla algılayan turistlerin riskli algıladığı destinasyonlardan kaçınarak daha güvenli destinasyonlara yöneldiği belirtilmektedir (Sönmez ve Graefe 1998a).

Beklenti kuramının önemli varsayımlarından biri belirli bir değişikliğin olasılıktaki etkisinin imkânsıza veya kesinliğe yaklaştıkça arttığı yö- nündedir (Kahneman ve Tversky 1979). Buna göre, algılanan olasılık imkânsızdan yüzde 1'e değişirse bunun risk algısı üzerinde yüzde 10'dan yüzde 11'e olan değişime göre daha büyük etkisi olmaktadır. Diğer bir ifadeyle önemli olan olasılıktaki mutlak artış değil, göreceli artıştır. Bu nedenle terör olaylarının nadiren gerçekleştiği destinasyonlarda örgütlü bir saldırı yaşand1ğında talepte ani düşüşler görülmektedir. Diğer yandan örgütlü terör saldırılarının sık yaşandığ destinasyonlarda meydana gelen yeni bir sald1rinın destinasyonu ziyaret eden turist sayısında büyük bir etki yaratmaması "Azalan Duyarlılık Psikofiziği" ile açıklanmaktadır (Wolff ve Larsen 2017). Örneğin, Ortadoğu'da sıklıkla yaşanan saldırılar toplumun dikkatini ve tepkisini çekmezken Paris'te meydana gelen saldırılar (2015), tüm dünyada büyük yankı uyandırmıştır. Teröre alış1k olunmayan Avrupa ülkelerinde yaşanan saldırılar da tepkiye neden olmuş ve bireylerin dünyayı "daha tehlikeli bir yer" olarak algılamalarına yol açmıştır (Brun vd. 2011; Larsen vd. 2011).

Riske duyarlı ve riskten kaçınma eğilimi yüksek turistlerin destinasyon seçiminde güvenliğin belirleyici bir faktör olduğu kabul edilmektedir (Sönmez ve Graefe 1998a; Reisinger ve Mavondo 2005). Riskli kararlarda güvenli destinasyon alternatifinin seçilmesi "Bilgi Entegrasyonu Kuramı" (Information Integration Theory) ile açıklanmaktadır (Anderson 1981). Karar aşamasında çekici bir destinasyonun arkadaşlar tarafından tavsiye edilmesi, planlanan destinasyonda gerçekleşen bir terör saldırısı ve bu saldırının medyaya yansıması gibi durumlarda destinasyon hakkında oluşan izlenim, değerlendirme ve yargıların değişebileceği öngörülmektedir (Sönmez ve Graefe 1998a; Sönmez ve Graefe 1998b). Schroeder ve Pennington-Gray (2014) medya, seyahat uyarıları ve destinasyon hakkındaki internet yorumları gibi farklı kaynaklardan edinilen bilgilerin risk algısı üzerinde etkili olduğunu ve turistlerin elde ettiği tüm bilgileri değerlendirme süzgecinden geçirerek karar verdiklerini belirtmektedir. Potansiyel turistlerin seçeneklerini belirleyerek olumsuz bilgi edindiği destinasyonu alternatifler arasından çıkardığ 1 ileri sürülmektedir. Destinasyon seçildikten sonra karşılaşılan olumsuz bilgiler de karar verme sürecine entegre edilerek 
planların iptal edilmesine veya destinasyon değişikliğine yol açabilmektedir. Turistlerin terör olaylarının ardından etkilenen destinasyonlara seyahat etmemesi, ikame destinasyonlara kayması veya seyahatlerini iptal etmesi bilgi entegrasyonu kuramıla açıklanmaktadır (Sönmez ve Graefe 1998a; Sönmez ve Graefe 1998b).

Turizmde risk algısı çalışmaları, algılanan risk türleri, risk algısını etkileyen değişkenler, risk algısının satın alma davranışlarına, seyahat kararına ve destinasyon seçimine etkileri üzerinde yoğunlaşmaktadır (Sönmez ve Graefe 1998a; Sönmez ve Graefe 1998b; Reisinger ve Mavondo 2005; Fuchs ve Reichel 2006; Kozak vd. 2007; Lepp ve Gibson 2008; Ateşoğlu ve Türker 2013; Çetinsöz ve Ege 2013; Karamustafa vd. 2013). Turistlerin risk alma, risk azaltma ve riskten kaçınma gibi davranışlarına odaklanan araştırmalar da bulunmaktadır (Fuchs ve Reichel 2011; Lo vd. 2011a; Lo vd. 2011b; Çetinsöz ve Ege 2012; Ritchie vd. 2017). Yerli alanyazında konuyla ilgili çalışmalar sınırlı olmakla birlikte doğrudan terörün turistlerin risk algıları ve davranışları üzerindeki etkilerine odaklanan bir araştırmaya rastlanamamıştır.

\section{YÖNTEM}

Araştırmanın temel amacı, hipotez test etmek veya genellemeler yapmak değil, sınırlı olarak çalışılmış konuyu ayrıntılı biçimde ele almak, verileri derinlemesine incelemek ve yeni bakış açıları keşfetmektir. Bu nedenle çalışmada nitel araştırma yöntemi benimsenmiş ve Maxwell'in (2013) amaç, kavramsal ve kuramsal çerçeve, araştırma sorularl, yöntem ve geçerlik bileşenlerinden meydana gelen "Etkileşimli Nitel Araştırma Tasarımı" modeli temel alınmıştır. Araştırmanın verileri, derinlemesine görüşme ve senaryo teknikleri aracllığıyla toplanmıştır.

Verilerin zengin bir içerik sunması ve farklı bakış açılarını ortaya koyarak konuyu daha iyi açıklaması için katılımcıların seçiminde amaçlı örnekleme yöntemlerinden biri olan maksimum çeşitlilik örneklemesi tercih edilmiştir. Bu yaklaşım, mekânlarda veya bireylerde farklı olan baz1 kriterleri belirleyerek bu kriterlere göre farkl1lık gösteren mekânları veya katılımcıları seçme prensibine dayanmaktadır. Maksimum çeşitlilik, farklılıkların neden olduğu algı, deneyim ve bakış açılarını açığa çıkarmaya ve konuyu bütünüyle betimlemeye firsat tanımaktadır (Creswell 2016). Çalışmada maksimum çeşitliliği sağlamak için milliyet, turist tipolojisi, mekân ve zaman çeşitliliği ölçütleri kullanılmıştır. Örneğin, zamansal çeşitlendirmenin başlıca nedeni yüksek ve düşük sezonlarda Türkiye'ye gelen turist profilinin değişkenlik göstermesi ve turistlerin risk algılarinda farklılıklar izlenebilmesidir. Bu kapsamda görüşmeler, Nisan-Eylül 2018 tarihleri arasında mekânsal çeşitliliği sağlamak amacıyla Pamukkale Travertenleri ve Antik Kleopatra Havuzu çevresi (Denizli), Meryem Ana Evi (Selçuk/İzmir), Marmaris'te otel restoranları ve plaj çevresi (Muğla), Alanya Kalesi ve Alanya'daki otel restoranlarn ile Side Antik Kenti (Antalya) olmak üzere beş farklı destinasyonda yürütülmüştür. Araştırmada milliyet sınırlandırmasına gidilmemiş ve çeşitli milliyetlerden kırk beş yabancı turistle yüz yüze derinlemesine ve senaryo görüşmeleri gerçekleştirilmiştir.

Araştırmanın verileri, görüşme yapmayı kabul eden katılımcılardan birbirini takip eden iki aşamada toplanmıştır. Öncelikle derinlemesine görüşmeler gerçekleştirilmiş, akabinde senaryolar okutularak görüşme yoluyla senaryolara dair sorular yöneltilmiştir. Derinlemesine görüşme soruları; a) sosyo-demografik bilgiler, b) geçmiş seyahat ve Türkiye deneyimleri, c) Türkiye hakkındaki bilgiler ve güncel seyahat tercihleri ve d) Türkiye'ye yönelik risk algısı ile algılanan riski azaltma stratejilerini öğrenmeye yönelik sorular olmak üzere dört grup altında toplanmıştır. İlk üç soru grubu, bireylerin algıları ve bakış açıları üzerinde etkili olmaları nedeniyle araştırmaya dahil edilmiștir. Turistlerin terör riski algısını tespit etmek için Fuchs ve Reichel (2006) ile Fuchs vd. (2012); risk azaltma stratejilerini ortaya koymak için ise Fuchs ve Reichel (2011) tarafından yürütülen araştırmalardan yararlanılmıştır. Katılımcıların terör riski algısını ve riski rasyonelleştirme yollarını anlamak için uygulanan senaryolara yönelik sorular, Uriely vd. (2007) ile Fuchs vd.'nin (2012) araştırmalarından yola çıkılarak hazırlanmıştır.

Senaryo yöntemi, turistlerin önyargılarını ortadan kaldırarak Türkiye'ye ve teröre yönelik risk 
Tablo 1. İngiltere'nin Türkiye Seyahat Tavsiyesi (Senaryo 1)

" $X$ " Ülkesinde Terör Riskleri

Teröristlerin "X" ülkesinde saldırılar gerçekleştirme intimalleri oldukça yüksektir. [Ülkede] bazı terör örgütleri aktiftir. 2015'ten beri ülkenin bazı bölgelerindeki terör faaliyetlerinde artış olmuştur. Başkent de dahil olmak üzere diğer büyük şehirlerde örgütler tarafından intihar saldırılarını da içeren birçok saldırı gerçekleştirilmiştir. Terör örgütleri açıkça " $X$ " ülkesindeki turistik alanlara saldırmakla tehdit etmiştir.

Saldırılar rastgele olabilir ve yabancılar tarafından ziyaret edilen yerleri etkileyebilir.

Bu ülkede havacılık endüstrisine yönelik artan bir terör saldırısı riski vardır. Havalimanlarındaki güvenlik görevlileriyle tamamen iş birliği yapmalısınız.

Önemli dini günler ve resmi tatillerde tetikte olun; terör örgütleri bazen böyle zamanlarda saldırı çağrısında bulunurlar.

Ocak 2017'de "X" şehrindeki bir gece kulübüne bir saldırı gerçekleştirildi, [bu saldırıda] 39 kişi öldü ve 69 kişi yaralandı.

Aralık 2016'da "X" şehrinde popüler bir bölgede yer alan futbol stadının yakınlarında bir araç patlatıldı. [Bu patlamada] çoğu polis memuru 44 kişi öldü ve 150 'den fazla kişi yaralandı.

Tedbirli olun, çıkan haberleri ve seyahat uyarılarını takip edin.

Kaynak: FCO 2017.

algılarını ve riskle başa çıkma yollarını öğrenmek ve terörün turistlerin davranışları üzerindeki etkilerini ortaya koyabilmek amaciyla uygulanmiştır. Bu kapsamda İngiltere (Tablo 1) ve ABD (Tablo 2) Dışişleri Bakanlıkları tarafından 2017 yılında Türkiye hakkında yayınlanan iki resmi seyahat uyarısı/tavsiyesi senaryo olarak kullanılmiştır.

Katılımcıların zaman kısıtları nedeniyle ve okuma kolaylığı sağlamak amacıyla uyarı metinlerindeki bazı ifadeler orijinallerine uygun biçimde kısaltılmıştır. Senaryo tekniği uygulanırken ülke bilgileri katılımcılarla önceden paylaşılmamış, yer adları " $X$ " ve " $Y$ " ülkesi/şehri olarak değiştirilmiştir.
Görüşme ve senaryo verilerinin çözümlenmesinde niteliksel içerik analizi uygulanmıştır. İlk olarak derinlemesine ve senaryo görüşmelerinin ses kayıtları yazıya dökülmüş, ardından ilk görüşme metni dikkatlice okunarak bir kod listesi çıkarılmıştır (açık kodlama). Aynı işlem ikinci metne uygulanmış ve elde edilen kodlar ilk listeyle karşılaştırılarak bir kod şeması hazırlanmiştır. Diğer görüşme metinlerinin kodlama işlemleri tamamlandiktan sonra yinelenen kodlar arasındaki ilişki ve örüntüler açı̆̆a çıkarılarak bunlar ana ve alt kategoriler altında toplanmıştır (eksenel kodlama) (Patton 2018). Kategoriler ve alt kategoriler, araştırmanın soruları ve amaçları doğrultusunda kuramsal altyapı temelinde oluş-

Tablo 2. ABD’nin Türkiye Seyahat Uyarısı (Senaryo 2)

" $Y$ " Ülkesinde Terörizm

Dışişleri Bakanlığı, özellikle tatil sezonu boyunca " $Y$ " ülkesinde artan terör saldırıları riskine karşı vatandaşları uyarmaktadır.

"Y" ülkesinde vatandaşlarımız ve çıkarlarımıza yönelik terör saldırılarının potansiyeli hala yüksektir.

" $Y$ " ülkesi [için yayınlanan] en son seyahat uyarısında da belirtildiği gibi ülkedeki büyük etkinliklerde, turistik yerlerde, restoranlarda, ticaret merkezlerinde, ibadet yerlerinde ve havayolu hizmetleri, metrolar, otobüsler, köprüler, otobüs terminalleri ve deniz taşımacılığı dahil olmak üzere ulaşım merkezlerinde ilave saldırılar gerçekleşebilir.

Dışişleri Bakanlığı Eylül 2017'de "Y" ülkesi için [yayınladığı] seyahat uyarısını; vatandaşların ülke çapında artan terör tehdidinden haberdar olmaları, bu sıralarda " $Y$ " ülkesine gitme gerekliliğini dikkatlice değerlendirmeleri ve ülkenin bazı bölgelerine yapılacak seyahatlerden kaçınmaları için güncellemiştir.

Kaynak: TSG 2017. 
Tablo 3. Örnek Kodlama Şeması

\begin{tabular}{|c|c|c|c|}
\hline Tema & Kategori & Alt Kategori & Alıntı \\
\hline \multirow{5}{*}{$\begin{array}{l}\text { Terör Riski ile } \\
\text { Başa Çıkma } \\
\text { Davranışları }\end{array}$} & \multirow[b]{2}{*}{ Risk Azaltma } & $\begin{array}{l}\text { Bilgisel stratejiler/ } \\
\text { Tavsiye Alma }\end{array}$ & $\begin{array}{l}\text { Arkadaşlarımızdan bazıları iki kere buraya geldiler ve sorun } \\
\text { olmadığını söylediler. O yüzden biz de geldik. (Katıımcı 35) }\end{array}$ \\
\hline & & $\begin{array}{l}\text { Seyahat } \\
\text { stratejileri/ Bireysel } \\
\text { güvenlik önlemleri }\end{array}$ & $\begin{array}{l}\text { Tur planını yaparken o bölgeye [sınır] gitmekten kaçındık. } \\
\text { Tüm ülkeler o tarafa gitmeyin diye uyarıyor. (Katıımcı 17) }\end{array}$ \\
\hline & \multirow{3}{*}{$\begin{array}{l}\text { Risk } \\
\text { Rasyonelleştirme }\end{array}$} & $\begin{array}{l}\text { Dışsal } \\
\text { rasyonelleştirme }\end{array}$ & $\begin{array}{l}\text { Her yerde bir risk olduğunu biliyorum, NewYork'ta da risk var, } \\
\text { benim ülkemde de risk var. (Katılımcı 28) }\end{array}$ \\
\hline & & $\begin{array}{l}\text { İçsel } \\
\text { rasyonelleştirme }\end{array}$ & $\begin{array}{l}\text { Bence saldırılardan sonra burası her zamankinden daha } \\
\text { güvenli. (Katılımcı 6) }\end{array}$ \\
\hline & & $\begin{array}{l}\text { Kişisel } \\
\text { rasyonelleştirme }\end{array}$ & $\begin{array}{l}\text { Yanlış zamanda yanlış yerde olabilirsin. Evde de olabilirsin } \\
\text { ama yine de patlayabilirsin. (Katılımcı 13) }\end{array}$ \\
\hline
\end{tabular}

turulmuş ve adlandırılmıştır (Creswell 2016). Araştırmanın verileri çözümlenirken uygulanan kodlama süreci ile ilgili örnek şema, Tablo 3'te gösterilmektedir.

Araştırmanın geçerlilik ve güvenilirliğini sağlamak için nitel araştırmalarda benimsenen inandırıcılık, aktarılabilirlik, tutarlılık ve doğrulanabilirlik ölçütleri sağlanmıştır (Guba 1981; Shenton 2004; Patton 2018). Inandırıcılık, veri kaynaklarını (alanyazın taraması, saha uygulamaları), uygulama alanını ve zamanını, katılımcıları ve analizcileri çeşitleme; uzman araştırmacılarla bilgilendirme toplantıları yapma; araştırma tasarımı, araştırma sorularının oluşturulması ve analizlerin yürütülmesinde akran denetimi ve bulguları literatürle karşılaştırma, aktarılabilirlik, karşılaştırmalar yapmak için araştırma hakkında ayrıntılı açıklamalar yapma; ayrıntılı betimlemeler yapma ve doğrudan alıntılar kullanma, tutarlılık, örtüşen yöntemler uygulama (derinlemesine görüşme, senaryo tekniği); görüşmeleri kaydederek yazıya dökme; çoklu kodlayıcı kullanma (gizli/blind kodlama, kodlayıcılar arasında yüzde 90 görüş birliği), doğrulanabilirlik, araştırmacı yanlılığ1nı azaltmak için çeşitleme yapma; araştırmanın yöntemini ve sınırlılıklarını belirtme gibi kriterler yerine getirilerek sağlanmıştır.

\section{BULGULARIN YORUMLANMASI}

Araştırmaya katılan turistler, 19-73 yaş aralığındadır; Amerika, Avrupa, Asya, Avustralya ve Afrika kıtalarındaki birçok farklı ülkeden Türkiye'ye gelmiştir. Katılımcıların büyük çoğunluğu en az lise mezunudur ve cinsiyet dağ1lımları birbirine oldukça yakındır. Katılımcılar arasında öğretmen, acenteci, otel sahibi, arkeolog, hemşire, veteriner, akademisyen, pazarlamac1, bankacı, mali müşavir, mühendis, öğrenci ve emekliler bulunmaktadır.

Katılımcılar, genellikle uluslararası seyahatlere katılan deneyimli turistlerden meydana gelmektedir. Geçmiş deneyimlerinde dünya çapında terörden etkilenen ülkeler dahil olmak üzere birçok ülkeyi ziyaret etmişlerdir. Katılımcılar arasında geçmişte düzenli olarak Türkiye'yi ziyaret eden turistler de bulunmaktadir.

Çoğunlukla tatil amacıyla ve çift olarak veya aileleriyle seyahat eden katılımcıların Türkiye'de kalış süreleri en az beş, en fazla on sekiz gündür ve ortalama geceleme sayısı 10'dur. İstanbul, An- 
talya, Kapadokya, Efes, Pamukkale ve İzmir, en fazla ziyaret edilen destinasyonlardır. Türkiye'ye ilk kez gelen katılımcılar daha çok kültür motivasyonuna sahiptir ve birden fazla destinasyonu ziyaret etmiştir. Türkiye' nin devamlı ziyaretçileri ise genellikle her zaman gittikleri tatil beldelerini tercih etmiştir. Katılımcılar, seyahatlerini çoğunlukla kendileri düzenlemiş, bununla birlikte seyahat acentası/tur operatörü aracılığıyla gelen veya Türkiye'deki acentalardan rehberli turlar satın alan katılımcılar da olmuştur.

\section{TURISTLERIN TÜRKIYE'YE YÖNELIK RISK ALGISI}

Genel konjonktür, siyasi karışıklıklar, Suriye ve Irak gibi tansiyonun yüksek olduğu sınır komşularından kaynaklanan jeopolitik sorunlar, sınır bölgelerde yaşanan olaylar ve benimsenen politikalar ile diplomatik ilişkiler turistlerin Türkiye'ye yönelik risk algısını şekillendirmiştir. Özellikle Suriye'de uzun süredir devam eden savaş orta$\mathrm{m}$ ve verilerin toplandığ 1 ilk döneme denk gelen (Nisan/2018) askeri müdahaleler ${ }^{1}$ ile Türkiye'nin bölgedeki tutumu, buranın da riskli olduğu alg1sını yaratmış ve bazı turistlerin seyahatleri hakkında endişe duymalarına yol açmıştır. Terör olayları, darbe girişimi ve Suriye'ye yakınlık turistlerin endişe duyduğu konular arasındadır:

\begin{abstract}
"Birkaç yıl önceki durum [terör saldırıları], sokaklardaki protestocular [Gezi Eylemleri], orduyla olan durum [darbe girişimi], İstanbul Havalimanı'nda gerçekleşen bombalı saldırı da var. Her yıl bir uyarıya denk geliyorsun gibi."
\end{abstract}

(Katılımcı 14, Erkek/58, İrlanda/İngiltere)

Turistlerin genel olarak Türkiye'ye dair güvenlik endişelerinin bulunmadığı göze çarpmıştır. Buna rağmen terör saldırılarından kaygılandığını belirten turistler de olmuştur. Turistlerin ortak düşüncesi, doğu, güneydoğu ve özellikle Suriye sınırının terör açısından riskli ve güvensiz olduğu yönündedir. Terörün risk algisını arttırdığ 1 ve turist talebini olumsuz yönde etkilediği, çeşitli çalışmalarda belirtilmektedir (Sönmez ve

\footnotetext{
${ }^{1}$ BBC (2018). ABD, İngiltere ve Fransa Suriye'deki Hedefleri Vurdu, https://www.bbc.com/turkce/haberler-dunya-43763637, Erişim tarihi: 14 Eylül 2018.
}

Graefe 1998a; Uriely vd. 2007; Fuchs vd. 2012). Bu çalışma da turistlerin riskli algıladığı bölgelere seyahat etmekten özellikle kaçındığını ortaya koymus,, Sönmez ve Graefe'nin (1998b) bulgularını desteklemiştir. Araştırmada İstanbul gibi büyük ve kalabalık şehirleri riskli gören turistlere de rastlanmıştır. Ancak turistlerin genel algisı turizm bölgelerinin diğer destinasyonlara göre daha güvenli olduğu şeklindedir:

\footnotetext{
"Resmi web sitesinden riskleri kontrol ettik... Şu an en yaygin [risk] terör ama büyük bir turist bölgesi olduğu için ve çok fazla güvenlik bulunduğu için Antalya ve Side civarında hiçbir şey olmadı̆̆ı açıktı."

(Katılımc1 24, Erkek/28, Sri Lanka/Almanya)
}

Katılımcılar, İstanbul'da gerçekleşen terör olaylarından daha fazla haberdar olmuştur. Turistlerin müdahil olduğu veya ziyaret edilen destinasyon özelindeki saldırılar daha fazla hatırlanmıştır. En fazla akılda kalan olaylar, İstanbul Atatürk Havalimanı (2016) ve Reina Gece Kulübü (2017) saldırılarıdır:

\begin{abstract}
"İstanbul Hipodromu [Sultanahmet saldırısı] vardl. Istiklal'de bir tane vardı ve Reina gece kulübü vardl. Beşiktaş Stadyumu yakınında bir terör saldırısı vardı ve tüm bunlar [arka arkaya] yaşandı. Bir de tabii ki Atatürk Havalimanı vardı. Bunlar elbette bizi endişelendirdi."
\end{abstract}

\section{(Katılımc1 26, Erkek/50, Almanya)}

Havalimanı saldırısının çoğu turist tarafından hatırlanmasının, İstanbul'un çekici bir destinasyon olmasının yanında saldırıların uluslararası medyada yer almasından, turistleri doğrudan ilgilendirmesinden ve gerçekleştiği zaman diliminde İstanbul aktarmalı uluslararası uçuşları etkilemesinden kaynaklandığı düşünülmektedir.

Seyahati sırasında terör riski algılayan veya güvensiz hisseden hiçbir katılımcı olmaması, önemli bulgular arasındadır. Turistler, endişeleri olsa bile geldikten sonra burayı güvenli bulmuştur. Genel bellek araştırmaları da olay gerçekleştikten sonraki ilk aşamada hafızanın çok hızlı kaybolduğunu ve tatil motivasyonu içindeyken savaş ve terör gibi dehşet verici olayların unutulduğunu ortaya koymaktadır (Larsen vd. 2011). 


\section{TURISTLERIN TERÖR RISKI ILE BAŞA ÇIKMA DAVRANIŞLARI}

Alanyazında turistlerin riskle başa çıkmak için riski azaltma ve rasyonelleştirme şeklinde iki davranış biçimi sergilediği belirtilmektedir (Uriely vd. 2007; Fuchs ve Reichel 2011; Fuchs vd. 2012). Bu çalışma da katılımcıların terör karşısında benzer davranışlar benimsediğini ortaya koymuştur (Şekil 1).

\section{Risk Azaltma}

Turistlerin terör riskini azaltmak için bilgisel ve seyahat ile ilgili olmak üzere iki temel strateji uyguladığı tespit edilmiştir (Şekil 2). Alanyazında bilgisel stratejilerin belirsizliği ortadan kaldırmak ve güveni arttırmak, seyahat stratejilerinin ise risklerin olumsuz sonuçlarını azaltabilmek için kullanıldığı belirtilmektedir (Lo vd. 2011a; Lo vd. 2011b).

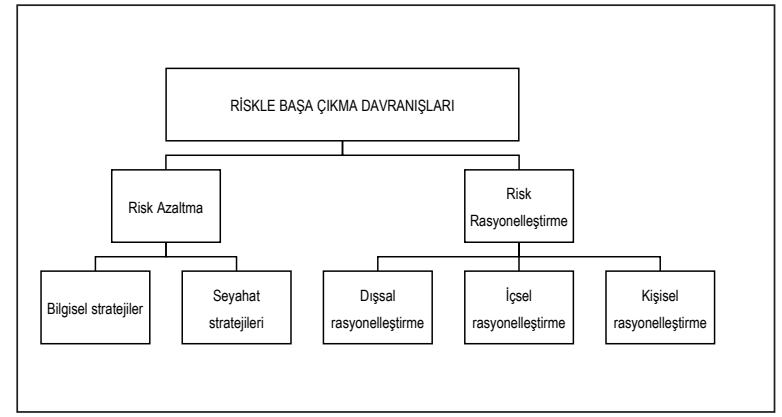

Şekil 1. Turistlerin Terör Riskini Azaltma Stratejileri

Destinasyon hakkında güncel bilgi edinmenin risk azaltmada en fazla kullanılan stratejiler arasında olduğu bilinmektedir (Fuchs ve Reichel 2011; Lo vd. 2011a; Lo vd. 2011b). Turistler, özellikle bilinmeyen destinasyonlara yapacakları ziyaretlerde karşılaşabileceği riskleri öğrenip önlemler alabilmek için destinasyon hakkındaki güncel bilgileri araştırmıştır:

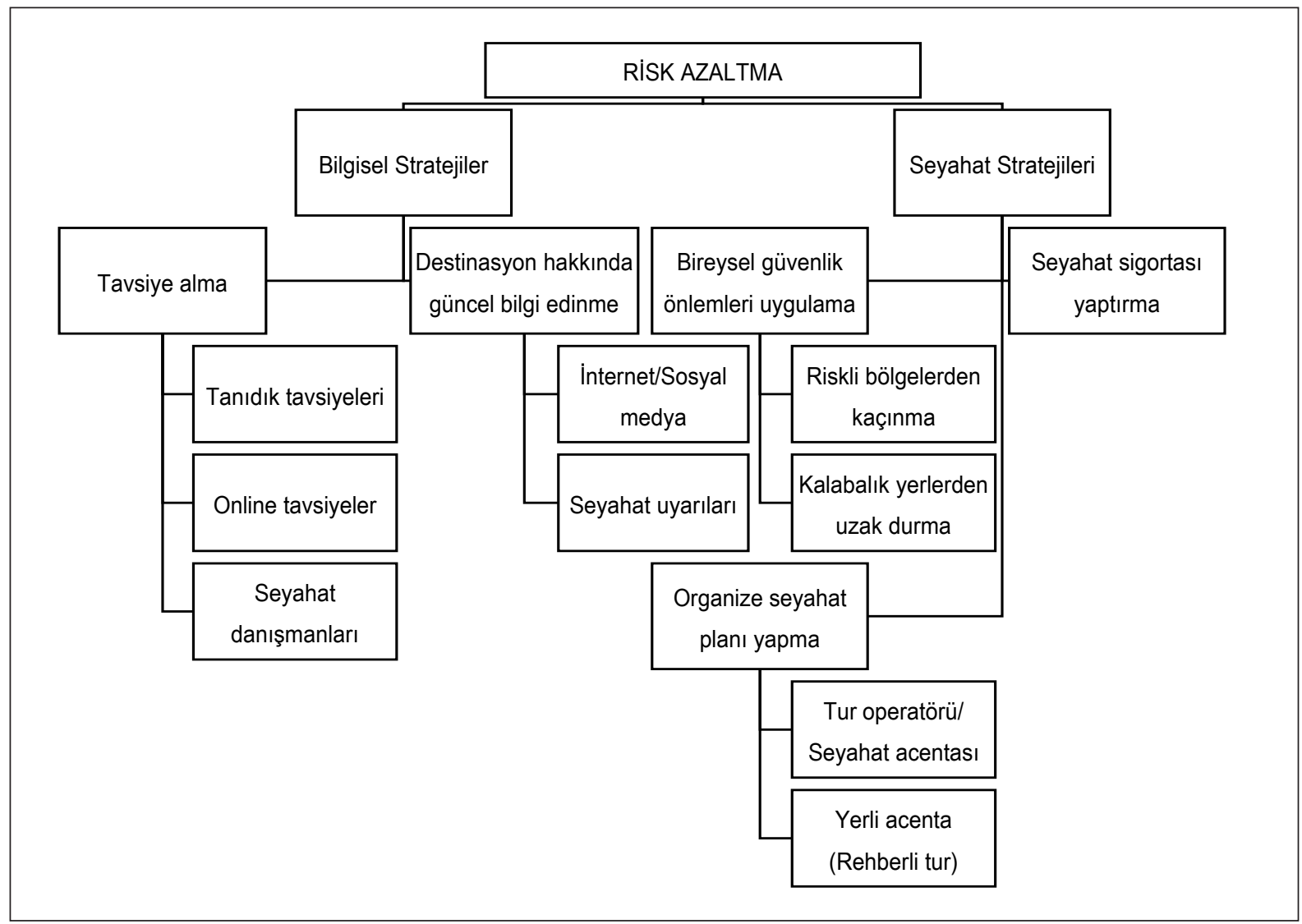

Şekil 2. Turistlerin Terör Riskini Azaltma Stratejileri 
"Son zamanlarda yaşanan herhangi bir terör saldrisı var mi veya başka bir şey oldu mu diye kontrol ettim. Suriye sınırı dışında her şey çok iyi görünüyordu."

(Katılımcı 17, Kadın/29, Hindistan)

Turistlerin risklerini azaltmak için kullandığ 1 önemli güncel bilgi edinme kaynaklarından biri de resmi seyahat uyarıları olmuştur. Ritchie vd. (2017) de seyahat uyarılarının risk azaltmada sıklıkla kullanıldığını ifade etmektedir.

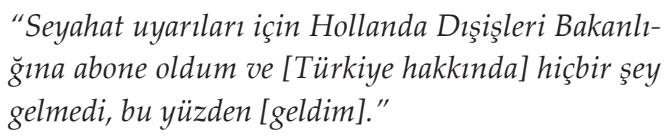

(Katılımcı 11, Erkek/65, Hollanda/Filistin)

Ağıdan ağıza iletişim bağlamında deneyimi bizzat kendisi yaşayan kişilerin verdiği bağımsız tavsiyelerin destinasyonu ziyaret edecek turistler tarafından daha fazla dikkate alındığı bilinmektedir (Lo vd. 2011a; Çetinsöz ve Ege 2012). Turistlerin risk azaltmada en fazla kullandığ bilgisel stratejilerden bir diğeri tavsiye almaktır:

\footnotetext{
"Arkadaşlarımızdan bazıları iki kere buraya geldiler ve sorun olmadığını söylediler. O yüzden biz de geldik."
}

(Katılımc1 35, Erkek/66, İngiltere)

Güvenlikle ilgili endişelerin gerçek risklerden çok bilgi eksikliğinden kaynaklandığ 1 ve turistlerin destinasyon hakkında güvenilir ve tarafsız bilgi kaynaklarına ihtiyaç duyduğu belirtilmektedir (Sharpley vd. 1996). Bu çalışmada farklı kanallardan edinilen bilgilerin turistlerin kararları üzerinde etkili olduğu ve turistlerin yeni öğrendiği tüm bilgileri değerlendirme sürecinden geçirerek planlarına yön verdiği görülmüştür. Elde edilen bu bulgular, bilgi entegrasyonu kuramını desteklemiştir.

Turistler destinasyonlarda karşılaşabileceği risklerden kaçınmak için seyahatle ilgili riskleri azaltmaktadır (Lo vd. 2011a; Lo vd. 2011b; Ritchie vd. 2017). Katılımcıların en çok kullandığı seyahat stratejilerinin başında riskli bölgeden $\mathrm{ka}$ çınma ve kalabalık yerlerden uzak durma gelmiştir. Alanyazında da turistlerin sıklıkla terör saldırılarının yaşandığı yerlerden uzak durma eğilimi gösterdiği belirtilmektedir (Uriely vd. 2007; Rittichainuwat ve Chakraborty 2009). Turistlerin Türkiye'deki güvenlik ve terör riski karşısında hemfikir olduğu en önemli konu, güneydoğu bölgesi ile Suriye sınırının çok riskli ve uzak durulması gereken yerler olduğudur.

\section{Risk Rasyonelleştirme}

Turistlerin algıladığ1 risklerle başa çıkmak için başvurduğu yollardan bir diğeri, riski rasyonelleştirme olmuştur. Uriely vd. (2007), turistlerin terör riskini "içe yönelik" ve "dışa yönelik" olarak iki şekilde rasyonelleştirdiğini ortaya koymuştur. Fuchs vd. (2012), “tatil zamanı ve mekânını rasyonelleştirme", "evdeki risklerle karşılaştırma" ve "risk şansını düşük görme" olmak üzere rasyonelleştirmeyi üç boyut altında toplamıştır. Bu çalışmada ise Uriely vd.'nin (2007) ortaya koyduğu rasyonelleştirme yollarına yeni bir boyut eklenmiş ve turistlerin terör riskini dışsal, içsel ve kişisel olarak rasyonelleştirdiği görülmüştür (Şekil 3).

\section{Dışsal Rasyonelleştirme: Dünyada Her Yer Riskli}

Dişsal rasyonelleştirme geliştiren turistler, terör riskinin küresel özellik taşıdığına, tehlikenin Türkiye'ye özgü olmadığına ve günümüzde her yerin terör açısından riskli olduğuna inanmaktadır. Bu bakış açısı, Beck'in (2006) risk toplumu kuramıla bağdaşmaktadır. Alanyazında özellikle IŞİD'in ortaya çıkışıyla birlikte terör olaylarının ciddi biçimde arttığı, olayların doğası ve rastlantısallığ 1 bakımından hiçbir destinasyonun bu riskten kaçamadığ 1 ileri sürülmektedir (Walters vd. 2019).

“...Türkiye de Ingiltere veya İtalya kadar güvenli. Bugün terör açısından güvenli hiçbir yer yok."

(Katılımcı 8, Kadın/30, İtalya)

Çalışmada kendi ülkesinin risk taşıdığını hatta etkilenen destinasyondan daha riskli olduğunu düşünen turistler de olmuştur. Alanyazında M1sır ve Tayland'a seyahat eden turistlerin oldukça benzer rasyonelleştirmeler yaptığ ${ }_{1}$ ortaya konmuştur (Uriely vd. 2007; Rittichainuwat ve Chakraborty 2009; Fuchs vd. 2012). Turistlerin özellikle 11 Eylül 2001 sonrasında teröre karşı başlatılan 
Burçin Kırlar Can - Işı Özgen

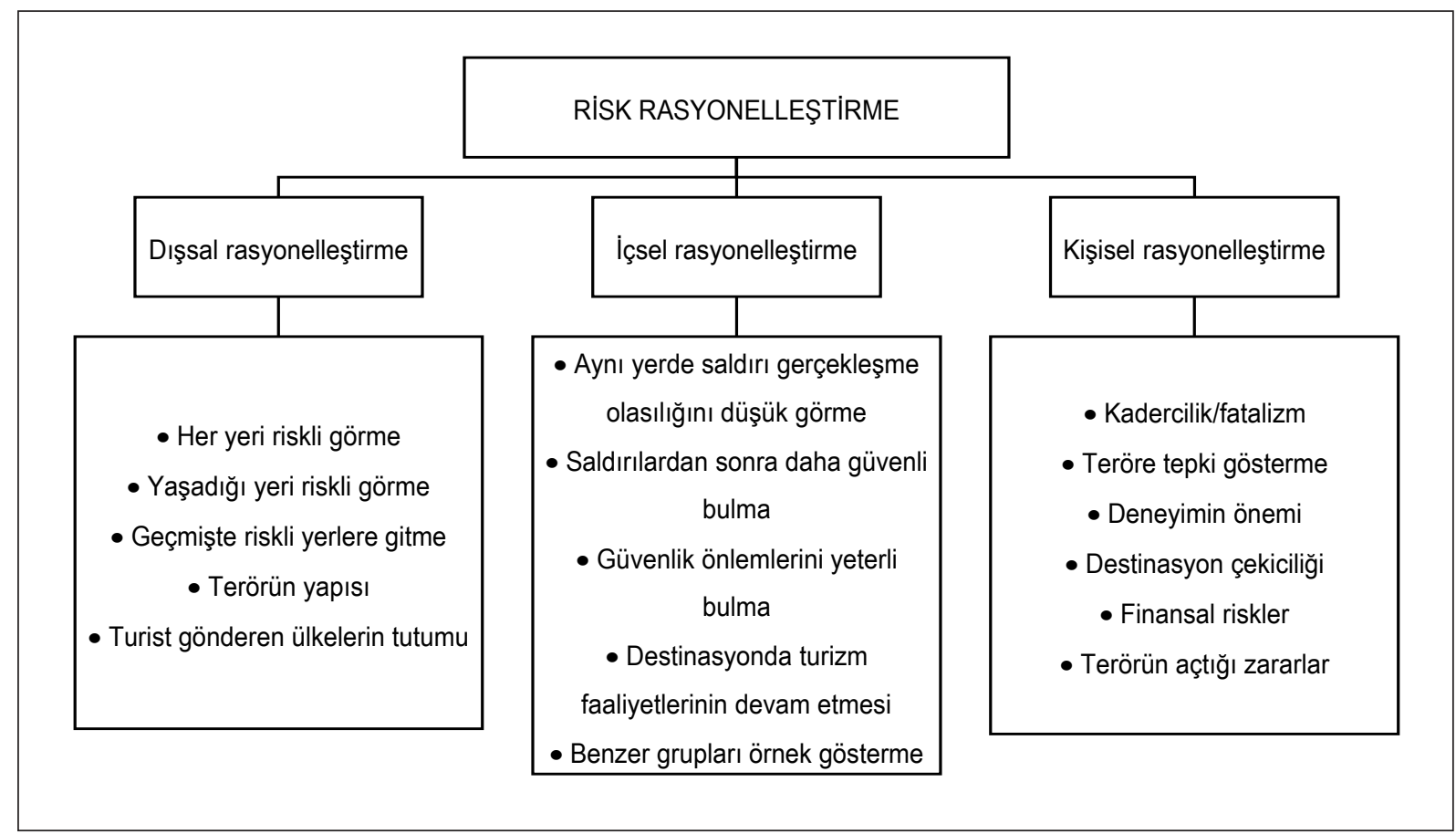

Şekil 3. Turistlerin Terör Riskini Rasyonelleştirme Yolları

savaşın ardından dünyayı daha tehlikeli buldukları ortaya konmuştur (Brun vd. 2011; Larsen vd. 2011). Bu durum bilişsel psikolojide "geçmişi daha güzel hatırlama" (rosy retrospection) eğilimiyle açıklanmaktadır (Wolff ve Larsen 2017).

Terör olaylarının öngörülememesi turistleri dışsal rasyonelleştirmeye iten nedenler arasında yer almıştır. Turistlerin geçmişte riskli destinasyonlara seyahat etmesi, turist gönderen ülkelerin hedef destinasyonlar için benzer uyarılar yapması veya aşırı tedbirli tutumları da turistlerin dışsal rasyonelleştirme yapma nedenlerindendir:

"Terör saldırılarının dünyanın herhangi bir yerinde her an gerçekleşebileceğine inanıyorum."

(Katılımcı 20, Erkek/46, İngiltere)

\section{İçsel Rasyonelleştirme: Kumarbaz Yanılgısı}

İçsel rasyonelleştirme yapan turistler, destinasyonun güvenli ve risksiz olduğunu düşünmekte, genel olarak Türkiye'yi güvenli bulmakta ve terör olaylarının ardından ülkede yeterli güvenlik önlemlerinin alındığını savunmaktadır. Fuchs vd. (2012) de sıklıkla terör olaylarının yaşandığı Mısır'da saldırılardan sonra güvenliğin arttığına dair görüşler sunmuştur. Wolff ve Larsen (2014), Norveç'te gerçekleşen terör olaylarının ardından destinasyona yönelik risk algısının düşmesinin nedenini yeni uygulanan güvenlik önlemlerine bağlamıştır. Turistlerin içsel rasyonelleştirme yapmasının diğer nedeni, terör saldırılarının ardından aynı yerde saldırı gerçekleşmesi ihtimalini düşük gördükleri için Türkiye'yi eskisinden daha güvenli bulmalarıdır:

"[Terör saldırılarının] ayn yerde iki kere gerçekleş-

(Katılımcı 10, Erkek/54, Hollanda)

Elde edilen bu veriler, Fuchs vd.nin (2012) "risk şansını düşük görme" rasyonelleştirmesine uymaktadır. Alanyazında Misır ve Ürdün'e seyahat eden turistlerin de benzer varsayımlara dayandığ 1 ortaya konmuştur (Uriely vd. 2007; Buda 2016). Aynı yerde başka saldırı yaşanması ihtimalini düşük görme ve destinasyonu daha güvenli bulma durumu bilişsel psikolojide "kumarbaz yanılgısı" (gambler's fallacy) önyargısı ile açiklanmaktadır (Wolff ve Larsen 2014; Wolff ve Larsen 2017). Bu yanılg1 yazı tura atmaya da benzetilmektedir. Çünkü insan zihni üst üste "tura" 
geldikçe bir sonraki turda "yazı" gelme şansını daha yüksek görmektedir, oysa ki olasılık hep yüzde 50'dir. Bu doğrultuda kumarbaz yanılgısına düşen turistler, Türkiye'de üst üste terör saldırıları gerçekleştiği için yeni bir saldırı yaşanmayacağına ve buranın eskisinden daha güvenli olduğuna inanmıştır. Destinasyonun eskisinden daha güvenli bulunması, "geçmişi daha kasvetli ve karamsar hatırlama" (gloomy retrospection) eğilimine de dayandırılmaktadır (Wolff ve Larsen 2014).

Wolff ve Larsen (2017), turistlerin düştüğü kumarbaz yanılgısına terör olaylarının sıklığının ve faillerinin yapısının neden olduğunu tartışmıştır. Nadiren ve bağımsız failler tarafından gerçekleştirilen saldırılardan sonra turistlerin terör riski algısında bir düşüş yaşanması beklenmiş ancak bu hipotez desteklenememiştir. Türkiye açısından değerlendirildiğinde de bu hipotez geçerli olmamaktadır. Çünkü son yıllarda hem bağımsız hem de örgütlü saldırılara rağmen turistler Türkiye'yi güvenli bulmaya ve ziyaret etmeye devam etmiştir. Bu durumu azalan duyarlılık psikofiziği ve beklenti kuramıyla açıklamak mümkündür. Örneğin, 2015 yılında yaşanan terör saldırılarının ardından yabancı turist sayısında önceki yıla göre yaklaşık yüzde 1'lik bir düşüş yaşanması kuramı doğrulamaktadır. Öte yandan tek bir saldırıda duyarsızlık gözlenmiş olmasına rağmen olayların sıklığ 1 ve şiddeti arttıkça risk algısı da arttığ 1 için 2016 yılında talepte daha büyük daralmalar yaşanmıştır (KTB 2018).

Katılımcılar özellikle turizm bölgelerini daha güvenli algılamıştır. Diğer yandan seyahat edilen destinasyonun riskli bölgeye uzak olması içsel rasyonelleştirme ardında yatan nedenler arasındadır. Bu bulgular, Fuchs vd.'nin (2012) “tatil zamanını veya mekânını rasyonelleştirme" boyutu ile benzeşmektedir.

\section{Kişisel Rasyonelleştirme: Tehlikeyle Dans Edenler, Kaderciler}

Kişisel rasyonelleştirmenin ardında yatan en önemli neden kadercilik/fatalizm olarak ortaya çıkmıştır. Katılımcılar terörün her zaman ve her yerde yaşanabileceğine ve kaderin bunda belirleyici olduğuna inanmaktadır. Uriely vd. (2007) de turistlerin kaderci davranışlarına dair benzer bulgulara rastlamıştır. Kadercilik felsefesi, bireylerin değiştirme şansları olmadığı için gelecek hakkında çok fazla düşünmediğini ve şansa daha fazla inandığını savunmaktadır (Sobol-Kwapinska 2013).

\begin{abstract}
"Bu kader. Benim ülkemde bir hırsiz tarafindan da öldürülebilirsiniz, aynı şey. Ancak bazı insanlar çok korkuyorlar ve seyahat etmiyorlar... Bu insanlarm şansı[na bă̆ll], terör saldırıları gerçekleştiğginde yanlış zamanda yanlış yerde olmuş olmalısın."
\end{abstract}

(Katılımc1 12, Kadın/34, Arjantin)

Turistler teröre karşı koymak için de kişisel rasyonelleştirme yapmıştır. Terörü hayatlarına bir müdahale olarak algılayan bu turistler, yaşayacağı deneyimi daha önemli gördüğü için riskleri daha kolay tolere etmiştir. Buda (2016), oldukça benzer söylemlerde bulunduğunu tespit ettiğ $i$ böyle turistleri "tehlikeyle dans edenler" olarak adlandırmıştır.

"Terör yüzünden hayatımızı durduramayacağımızı

bilecek kadar akıllıyız."

(Katılımcı 2, Kadın/35, Avustralya/Dubai)

\section{SONUC}

Terör, turizmde yaşanan darboğazlarda yads1namayacak bir role sahiptir. 2017 yılı itibariyle terör bakımından daha sakin bir döneme girilen Türkiye'de terörün etkisi kısa sürede atlatılmış görünse de yaşanan olaylar ülke imajına ciddi zararlar vermiştir. Olayların sıklığı, şiddeti ve failleri Türkiye' nin Ortadoğu gibi algılanmasına yol açmıştır. Kriz sürecinde faaliyetlerini sonlandırmak zorunda kalan turizm işletmeleri ile sektörden ayrılan deneyimli iş gücü terörün ekonomik ve sosyolojik açıdan ülkeye ve turizm sektörüne verdiği zararı ortaya koymaktadır.

Bu çalışma turizm alanında sınırlı olarak çalışılmış risk algısı konusunu terör bağlamında ele almış, turistlerin davranışları arkasında yatan bilişsel süreçleri açığa çıkarmış ve risk altında alınan kararları açıklamak için kullanılan bazı kuramların varsayımlarını desteklemiştir. Araştırma özellikle riskle başa çıkma davranışları konusunda sunduğu verilerle alanyazına katkıda bulunmuş, turistlerin riski rasyonelleştirme yollarına yeni bir boyut kazandırmıştır. 
Çalışmanın ortaya koyduğu veriler, çoğu terör riskinin farkında olmasına rağmen Türkiye'ye seyahat eden katılımcılarla sinırlıdır. Riskten kaçındığı veya güvensiz bulduğu için Türkiye'ye gelmeyen turistlerin farklı risk algilarına sahip olduğu görüşünden hareketle, çalışmanın risk almaya ve riskleri azaltmaya eğilimli turistleri kapsadığını söylemek mümkündür. Risk alma eğilimi çoğunlukla heyecan arayışı ve macera motivasyonları ile ilişkilendirilse de (Lepp ve Gibson 2008) katılımciların heyecan veya macera peşinde olmadığı aksine riskin bilincinde olarak riskle başa çıkmak için çeşitli yollara başvurduğu görülmüştür. Bununla birlikte risk alma eğiliminin mevcut durum için geçerli olduğu ve olası krizlerde turistlerin farklı tutum ve davranışlar sergileyebileceği düşünülmektedir.

Destinasyonun terör ve risklerle anılan yerlere mesafesi arttıkça turistlerin daha güvende hissettiği ve daha az risk algıladığ 1 bilinmektedir (Pizam ve Mansfeld 2006). Bu araştırma da bu sonuçları desteklemektedir. Bu bağlamda Türkiye gibi jeopolitik açıdan göz önünde olan destinasyonların tanıtım ve pazarlama faaliyetlerinde ülkenin coğrafi büyüklüğu ile turizm çeşitliliğine vurgu yapması ve özellikle turizm destinasyonlarının güvenliğini ön plâna çıkarması önerilmektedir. Kriz anlarında güçlü bir iletişim ağı kurularak hedef pazarlara güncel veri akışı sağlanmasının terörün, diğer krizlerin ve bunlara bağlı seyahat uyarılarının olumsuz etkilerini azaltmada etkili olacağı düşünülmektedir.

Alanyazında terör riski algısına odaklanan ve terörün turistler üzerindeki etkilerini ortaya koyan sınırlı sayıda araştırmaya rastlanmaktadır. $\mathrm{Bu}$ araştırma da risklere dayanıklı ve risklerle başa çıkabilen turistlerle sınırlı olup duyarlılığı yüksek olan ve riskten tamamen kaçınan turistleri kapsamamaktadır. Turistlerin risk algısı çeşitli faktörlerden etkilenerek değişkenlik gösterdiği için gelecek araştırmalarda farklı ve büyük örneklemlerle çalışılması, konunun derinleştirilmesi; alanyazına ve destinasyon pazarlamacılarına sunacağı katkılar bakımından önem taşımaktadır.

Bu çalışmada seyahat uyarılarının turistler üzerinde ciddi etkileri olduğu belirlenmiştir. Gelecek araştırmalarda Türkiye'ye turist gönderen ülkelerin yayınladığ1 seyahat uyarılarına söylem analizi yapılarak turistlerin bakış açıları ile karşılaştırmalı biçimde ele alınması ve turistler üzerinde etkili unsurların açığa çıkarılması önerilmektedir. Riskle başa çıkma davranışlarından yola çıkılarak turist tipolojisi oluşturulmasının tanitım ve pazarlama faaliyetlerinde yol gösterici olması beklenmektedir.

\section{KAYNAKÇA}

Anderson, N. H. (1981). Foundations of Information Integration Theory. New York: Academic Press.

Ateşoğlu, İ. ve Türker, A. (2013). Türkiye'de Tatil Yapan Turistlerin Algıladıkları Risk Türleri, Seyahat ve Otel Işsletmeciliği Dergisi, 10 (3): 24-44.

Beck, U. (2006). Living in the World Risk Society, Economy and Society, 35 (3): 329-345.

Brun, W., Wolff, K. ve Larsen, S. (2011). Tourist Worries after Terrorist Attacks: Report from a Field Experiment, Scandinavian Journal of Hospitality and Tourism, 11 (3): 387-394.

Buda, D. M. (2016). Tourism in Conflict Areas: Complex Entanglements in Jordan, Journal of Travel Research, 55 (7): 835-846.

Çetinsöz, B., C. ve Ege, Z. (2012). Turistlerin Demografik Özelliklerine Göre Risk Azaltma Stratejileri: Alanya Örneği, Anatolia: Turizm Araştırmaları Dergisi, 23 (2): 159-172.

Çetinsöz, B., C. ve Ege, Z. (2013). Impacts of Perceived Risks on Tourists' Revisit Intentions, Anatolia: Turizm Araştırmaları Dergisi, 24 (2): 173-187.

Creswell, J. W. (2016). Nitel Araştırma Yöntemleri: Beş Yaklaşıma Göre Nitel Araştırma Deseni. (Çev. Editörleri) M. Bütün ve S. B. Demir. Ankara: Siyasal Kitabevi.

FCO (2017). Foreign Travel Advice, https://www.gov.uk/foreign-travel-advice, Erişim tarihi: 17 Ocak 2017.

Fuchs, G. ve Reichel, A. (2006). Tourist Destination Risk Perception: The Case of Israel, Journal of Hospitality $\mathcal{E}$ Leisure Marketing, 14 (2): 83-108.

Fuchs, G. ve Reichel, A. (2011). An Exploratory Inquiry into Destination Risk Perceptions and Risk Reduction Strategies of First Time vs. Repeat Visitors to a Highly Volatile Destination, Tourism Management, 32: 266-276.

Fuchs, G., Uriely, N., Reichel, A. ve Maoz, D. (2012). Vacationing in a Terror-stricken Destination: Tourists' Risk Perceptions and Rationalizations, Journal of Travel Research, 52 (2): 182-191.

Guba, E., G. (1981). Criteria for Assessing the Trustworthiness of Naturalistic Inquiries, Educational Communication and Technology Journal, 29 (2): 75-91.

Kahneman, D. ve Tversky, A. (1979). Prospect Theory: An Analysis of Decision under Risk, Econometrica, 47 (2): 263-291.

Karamustafa, K., Fuchs, G. ve Reichel, A. (2013). Risk Perceptions of a Mixed-Image Destination: The Case of Turkey's First-Time Versus Repeat Leisure Visitors, Journal of Hospitality Marketing E Management, 22 (3): 243-268. 
Kırlar-Can, B. (2018). Terör Riskine Yönelik Seyahat Uyarıları: Türkiye'ye En Fazla Turist Gönderen Ülkelerin Yaklaşımları, Türk Turizm Araştırmaları Dergisi, 2 (2): 21-33.

Kozak, M., Crotts, J. C. ve Law, R. (2007). The Impact of the Perception of Risk on International Travellers, International Journal of Tourism Research, 9: 233-242.

KTB (2018). Sınır İstatistikleri Yıllık Bülteni 2017, http://yigm. kulturturizm.gov.tr/TR-201114/yillik-bultenler.html, Erişim tarihi: 25 Nisan 2019.

Larsen, S., Brun, W., Øgaard, T. ve Selstad, L. (2011). Effects of Sudden and Dramatic Events on Travel Desire and Risk Judgments, Scandinavian Journal of Hospitality and Tourism, 11 (3): 268-285.

Lepp, A. ve Gibson, H. (2008). Sensation Seeking and Tourism: Tourist Role, Perception of Risk and Destination Choice, Tourism Management, 29: 740-750.

Lo, A. S., Cheung, C. ve Law, R. (2011a). Hong Kong Residents' Adoption of Risk Reduction Strategies in Leisure Travel, Journal of Travel \& Tourism Marketing, 28 (3): 240-260.

Lo, A. S., Law, R. ve Cheung, C. (2011b). Segmenting Leisure Travelers by Risk Reduction Strategies, Journal of Travel E Tourism Marketing, 28 (8): 828-839.

Maxwell, J. A. (2013). Qualitative Research Design: An Interactive Approach. California: Sage Publications.

Patton, M. Q. (2018). Nitel Araştırma ve Değerlendirme Yöntemleri. (Çev. Editörleri) M. Bütün ve S. B. Demir. Ankara: Pegem Akademi.

Piekarz, M., Jenkins, I. ve Mills, P. (2015). Risk and Safety Management in the Leisure, Events, Tourism and Sports Industries. Londra: CABI.

Pizam, A. ve Mansfeld, Y. (2006). Toward a Theory of Tourism Security. İçinde, Y. Mansfeld ve A. Pizam (Editörler), Tourism, Security and Safety: From Theory to Practice (ss.1-27). Burlington: Elsevier.

Reisinger, Y. ve Mavondo, F. (2005). Travel Anxiety and Intentions to Travel Internationally: Implications of Travel Risk Perception, Journal of Travel Research, 43: 212-225.

Ritchie, B. W., Chien, P. M. ve Sharifpour, M. (2017). Segmentation by Travel Related Risks: An Integrated Approach, Journal of Travel \& Tourism Marketing, 34 (2): 274-289.
Rittichainuwat, B. N. ve Chakraborty, G. (2009). Perceived Travel Risks regarding Terrorism and Disease: The Case of Thailand, Tourism Management, 30: 410-418.

Schroeder, A. ve Pennington-Gray, L. (2014). Perceptions of Crime at the Olympic Games: What Role does Media, Travel Advisories, and Social Media Play?, Journal of Vacation Marketing, 20 (3): 225-237.

Sharpley, R., Sharpley, J. ve Adams, J. (1996). Travel Advice or Trade Embargo? The Impacts and Implications of Official Travel Advice, Tourism Management, 17 (1): 1-7.

Shenton, A. K. (2004). Strategies for Ensuring Trustworthiness in Qualitative Research Projects, Education for Information, 22: 63-75.

Sobol-Kwapinska, M. (2013). Hedonism, Fatalism and "Carpe Diem": Profiles of Attitudes towards the Present Time, Time \& Society, 22 (3): 371-390.

Sönmez, S. F. ve Graefe, A. R. (1998a). Influence of Terrorism Risk on Foreign Tourism Decisions, Annals of Tourism Research, 25 (1): 112-144.

Sönmez, S. F. ve Graefe, A. R. (1998b). Determining Future Travel Behavior from Past Travel Experience and Perceptions of Risk and Safety, Journal of Travel Research, 37: 171-177.

TSG [Travel.State.Gov] (2017). Alerts and Warnings, https:// travel.state.gov/content/passports/en/alertswarnings.html, Erişim tarihi: 15 Ocak 2017.

Uriely, N., Maoz, D. ve Reichel, A. (2007). Rationalising Terror-Related Risks: The Case of Israeli Tourists in Sinai, International Journal of Tourism Research, 9: 1-8.

Walters, G., Wallin, A. ve Hartley, N. (2019). The Threat of Terrorism and Tourist Choice Behavior, Journal of Travel Research, 58 (3): 370-382.

Wolff, K. ve Larsen, S. (2014). Can Terrorism Make Us Feel Safer? Risk Perceptions and Worries Before and After the July 22nd Attacks, Annals of Tourism Research, 44: 200-209.

Wolff, K. ve Larsen, S. (2017). A Taxonomy of Terror - About the Effect of Different Kinds of Terror on Risk Perceptions, Scandinavian Journal of Hospitality and Tourism, 17 (2): 111-128. 

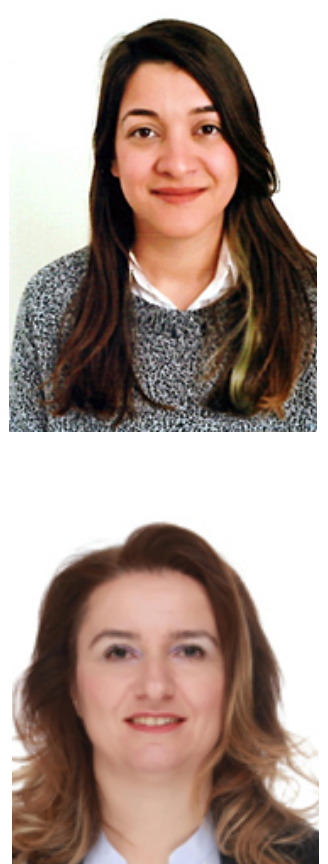

Burçin KIRLAR CAN

Ege Üniversitesi Çeşme Turizm ve Otelcilik Yüksekokulu Turist Rehberliği Bölümü’nden mezun oldu (2009). İlk yüksek lisans derecesini Ege Üniversitesi'nden Türk Sanatı Dalı'ndan aldı (2012). İkinci yüksek lisans derecesini Dokuz Eylül Üniversitesi Turizm İşletmeciliği Dalı’ndan aldı (2013). Doktora derecesini Dokuz Eylül Üniversitesi'nden Turizm İşletmeciliği Dalı'ndan aldı (2019). Pamukkale Üniversitesi'nde çalışmaya başladı (2011). Dokuz Eylül Üniversitesi İşletme Fakültesi Turizm İ̧̧letmeciliği Bölümü'nde (35. madde ile) çalışı (2012-2018). Halen Pamukkale Üniversitesi Turizm Fakültesi Turizm İşletmeciliği Bölümü’nde görev yapmaktadır. Temel çalışma alanları, turizm sosyolojisi, turist davranışı ve risk algısıdır. Ingilizce dilinde turist rehberidir.

\section{Işı ÖZGEN}

Dokuz Eylül Üniversitesi İşletme Fakültesi Turizm İșletmeciliği Bölümü’nden lisans derecesini aldı (1997). Dokuz Eylül Üniversitesi Sosyal Bilimler Enstitüsü Turizm İşletmeciliği Ana Bilim Dalı'nda yüksek lisansını (2000) ve doktorasını tamamladı (2005). Yönetim ve Strateji alanında doçent unvanını aldı (2013). Dokuz Eylül Üniversitesi İşletme Fakültesi Turizm İşletmeciliği Bölümü’nde araştırma görevlisi olarak başladığı (1997) akademik kariyerine aynı kurumda devam etmektedir. Gastronomi, turizm, yönetim ve organizasyon alanlarında ulusal ve uluslararası yayınları bulunmaktadır. İyi düzeyde İngilizce ve Fransızca bilmektedir. İngilizce dilinde turist rehberidir. 